\title{
Pengaruh Brainstorming Berbasis Copy The Master terhadap Efektivitas Aspek Retorika Tulis serta Implikasinya dalam Pembentukan Karakter Bangsa
}

\author{
N. Sueca ${ }^{1}$, M. Sutama ${ }^{2}$, I.B. Putrayasa ${ }^{3}$ \\ ${ }^{123}$ Program Studi Bahasa, Program Pascasarjana \\ Universitas Pendidikan Ganesha \\ Singaraja, Indonesia \\ e-mail: nengah.sueca@pasca.undiksha.ac.id ${ }^{1}$, made.sutama@pasca.undiksha.ac.id ${ }^{2}$, \\ bagus.putrayasa@pasca.undiksha.ac.id ${ }^{3}$.
}

\begin{abstract}
Abstrak
Penelitian ini bertujuan untuk mendeskripsikan efektivitas aspek retorika tulis karangan eksposisi, mendeskripsikan pengaruh brainstorming berbasis copy the master terhadap efektivitas aspek retorika tulis karangan eksposisi, dan mendeskripsikan implikasi brainstorming berbasis copy the master terhadap pembentukan karakter-bangsa siswa kelas X MIA SMAN 1 Semarapura. Populasi penelitian ini adalah seluruh siswa kelas X MIA SMAN 1 Semarapura dengan sampel kelas X MIA 2 dan X MIA 5. Penelitian ini menggunakan quasi eksperimen dengan rancangan nonequevalent posttest only control group design. Analisis data yang digunakan adalah analisis kuantitatif dan kualitatif. Analisis kuantitatif digunakan untuk menganalisis data efektivitas aspek retorika tulis karangan eksposisi dengan uji-t sampel independen. Analisis kualitatif digunakan untuk menganalisis data pembentukan karakter bangsa yang diperoleh dari hasil kuesioner. Hasil penelitian ini menunjukkan bahwa analisis ujit sampel independen menunjukkan nilai $t_{\text {hit }}=7,761(p=0,000<0,05)$ yang menandakan hipotesis nol $\left(\mathrm{H}_{0}\right)$ ditolak. Hasil analisis univariat data pembentukan karakter bangsa dengan brainstormning berbasis copy the master menunjukkan skor rata-rata sebesar 138,1875 dengan kualifikasi sangat tinggi. Hal tersebut menunjukkan ada pengaruh yang signifikan brainstorming berbasis copy the master terhadap efektivitas aspek retorika tulis karangan ekpsosisi dan ada implikasinya dalam pembentukan karakter-bangsa siswa SMAN 1 Semarapura.
\end{abstract}

Kata kunci: Brainstorming, Master, Aspek Retorika Tulis

\begin{abstract}
This research aimed to describe the effectiveness of writing rhetorical aspects of exposition essay, describe the influence of brainstorming based copy the master to the effectiveness of writing rhetorical aspects of exposition essay, and describe the implications of brainstorming based copy the master to the development of national-character in class X MIA students of SMAN 1 Semarapura. The population in this research was all students of class X MIA SMAN 1 Semarapura in which X MIA 2 and X MIA 5 became the sample. This research used a quasiexperimental with nonequevalent posttest only control group design. Analyses of the data used were quantitative and qualitative analysis. The quantitative analysis was used to analyze the data effectiveness of writing rhetorical aspects of exposition essay with independent samples $t$ test. Meanwhile, the qualitative analysis was used to analyze the data of the development of national-character obtained from the questionnaire. The result of this study showed that) analysis of independent samples $t$-test showed that thit value $=7.761(p=0.000<0.05)$ which means that the null hypothesis (Ho) is rejected; (3) the results of the univariate analysis of the data of the national-character development with brainstormning based copy the master showed an average score of 138.1875 with very high qualifications. It can be concluded that there is significant effect of brainstorming based copy the master to the effectiveness of writing rhetorical aspects of exposition essay and its implication in developing national-character students of SMAN 1 Semarapura.
\end{abstract}

Keywords: Brainstorming, Master, Writing Rhetorical Aspects 


\section{Pendahuluan}

Kegiatan berbahasa tidak bisa terlepas dari penggunaan suatu bahasa. Dalam peristiwa tersebut bahasa harus digunakan secara efektif. Untuk mendapatkan keefektifan itu diperlukan kemampuan beretorika dalam berbahasa. Menyinggung istilah retorika, selama ini kebanyakan orang mengenal retorika sebagai seni berbicara. Hal tersebut dikarenakan dari zaman Yunani sampai zaman Modern, kegiatan retorika lebih banyak ditekankan pada seni bertutur. Padahal, kegiatan beretorika tidak hanya mencakup kegiatan bertutur, tetapi juga menyangkut kegiatan menulis. Terkait hal tersebut, Sudiana (2007:21) menyatakan bahwa cakupan retorika tidak saja berkaitan dengan seni berbicara, tetapi juga berkenaan dengan keterampilan menyampaikan ide-pesan secara tertulis. Senada dengan hal itu, Syafi'le (1988:1) menyatakan bahwa retorika adalah seni kemampuan menyatakan pendapat, mengemukakan gagasan, menyampaikan informasi kepada orang lain secara efektif dengan menggunakan bahasa sebagai alatnya, baik secara lisan maupun tertulis. Hal itu membuktikan bahwa retorika tidak sebatas pada kegiatan bertutur, tetapi juga menyangkut kegiatan menulis.

Terkait hal tersebut, selama ini retorika belum begitu banyak ditekankan dalam keterampilan menulis. Padahal, keberhasilan keterampilan menulis sangat ditentukan oleh aspek retorika tulis. Untuk itu, dalam keterampilan menulis, aspek retorika tulis harus ditekankan, mengingat menulis merupakan salah satu keterampilan berbahasa yang paling kompleks. Berkaitan dengan hal itu, Kartono (2009:17) menyatakan bahwa menulis merupakan sebuah aktivitas yang kompleks, bukan sekadar mengguratkan kalimat-kalimat, melainkan lebih daripada itu. Menulis dipandang sebagai proses menuangkan pikiran dan menyampaikannya kepada khalayak. Sejalan dengan hal itu, Sumarjo (dalam Komaidi, 2011:5) menekankan bahwa menulis merupakan suatu proses melahirkan tulisan yang berisi gagasan. Oleh sebab itulah, kegiatan menulis tidak sekadar membuat kalimat, tetapi terjadi proses berpikir kritis secara intens dan kompleks.

Sebagai keterampilan berbahasa yang paling kompleks, menulis memiliki kedudukan strategis dalam pembelajaran Bahasa dan Sastra Indonesia. Keterampilan menulis digunakan untuk berpikir kritis oleh siswa. Selain itu, keterampilan ini juga digunakan untuk mengomunikasikan perasaan, pendapat, dan pengalamannya kepada orang lain. Dengan demikian, keterampilan menulis memiliki peran yang amat penting bagi siswa dalam pembelajaran. Mengingat penting dan kompleknya keterampilan menulis, sudah seharusnya kegiatan ini mendapat penekanan yang lebih serius dalam pembelajaran. Hal ini dilakukan karena kegiatan menulis tidak sekadar membuat tulisan, tetapi juga dituntut keefektifan tulisan yang dibuat.

Untuk mendapatkan keefektifan tersebut, tidak hanya diperlukan pengetahuan kebahasaan, tetapi juga di luar pengetahuan kebahasaan, seperti ide, bahan tulisan, model, serta pengembangan tulisan. Sejalan dengan itu, Sutarno (2009:11) menyatakan bahwa tulisan yang efektif mencakup beberapa aspek, seperti kandungan isi, nilai dan norma, metode penulisan, bahasa, penyajian, dan penampilan. Berkaitan dengan hal itu, Martha (2012:108) menyatakan bahwa paragraf (tulisan) yang baik, dalam artian komunikatif, harus memenuhi empat syarat kualitas retorika. Keempat syarat retorika tersebut adalah (1) kelengkapan (completeness), (2) kesatuan (unity), (3) keurutan (order), dan (4) kepaduan (coherence). Dengan demikian dapat disimpulkan bahwa untuk mendapatkan suatu keefektifan tulisan diperlukan kepiawaian menyusun aspek retorika tulis sehingga tercipta tulisan yang lengkap, satu, urut, dan padu. Tanpa memerhatikan aspek tersebut, tulisan terkesan asal-asalan, tanpa kesatuan, rancu, bahkan tidak jelas apa yang ditulis. Oleh sebab itu, aspek retorika tulis merupakan aspek terpenting dalam sebuah tulisan yang efektif.

Dari studi pendahuluan yang dilakukan di SMAN 1 Semarapura ditemukan beberapa indikator yang menunjukkan rendahnya keterampilan menulis. Indikator tersebut berkaitan dengan kemampuan menyusun aspek retorika tulis, pengorganisasian, mekanis, dan teknik dalam menulis. Sejalan dengan itu, diperoleh informasi dari Drs. I Gusti Ngurah Putra selaku guru bahasa Indonesia kelas X MIA SMAN 1 Semarapura bahwa kesulitan yang dialami siswa dalam kegiatan menulis, khususnya menulis eksposisi adalah menemukan ide, memulai sebuah tulisan, merangkai kalimat-kalimat menjadi paragraf yang padu, menyusun ide yang satu dan sistematis, serta menggunakan kata dan ejaan yang tepat. Semua itu adalah kesulitan aspek retorika yang dialami siswa dalam menulis karangan eksposisi di kelas X MIA SMAN 1 Semarapura. Hal itulah yang dikatakan menjadi penyebab rendahnya skor keterampilan menulis dalam pencapaian ketuntasan pembelajaran. 
Berdasarkan hal itu, penulis memandang brainstorming (sumbang saran atau curah pendapat) berbasis copy the master berkontribusi terhadap keefektifan aspek retorika tulis. Dengan brainstorming siswa lebih mudah menemukan atau mencurahkan idenya ke dalam tulisan. Hal ini sesuai dengan pendapat Goshgarian, dkk. (2002:65) yang menyatakan "Brainstorming can help you get your ideas on paper in an informal and unstructured way. When you brainstorm, you write down as many ideas as you can about your subject, usually in short phrases, question, or single word." Hal tersebut membuktikan bahwa brainstorming dapat membantu siswa untuk menemukan ide-ide tentang perihal pokok ke dalam tulisan, baik dalam bentuk frasa, pertanyaan, ataupun sebuah kata. Selain brainstorming, copy the master juga dapat memudahkan siswa dalam menemukan ide dan meniru model tulisan yang akan dibuat. Peniruan yang dilakukan bukan berarti menjiplak model aslinya, meliankan hanya meniru konsepnya saja. Sejalan dengan hal itu, Marahimin (2009:21) menyatakan bahwa yang dapat ditiru atau di-copy adalah kerangkanya, idenya, bahkan cara/tekniknya. Dengan demikian, prinsip copy the master perlu diterapkan agar hasil pembelajaran menulis dapat tercapai dengan baik.

Selain itu, penggunaan brainstorming berbasis copy the master juga berimplikasi terhadap pembentukan karakter bangsa. Implikasi tersebut dapat berupa kerja sama antarkelompok brainstorming, tangung jawab, perdamaian, dan persatuan, serta dapat juga berupa kejujuran, kedisiplinan, kemandirian, kesantunan, kekreatifan yang lahir dari kegiatan copy the master. Dengan demikian, brainstorming berbasis copy the master berpengaruh positif terhadap efektivitas aspek retorika tulis serta berimplikasi dalam pembentukan karakter bangsa.

Berdasarkan latar belakang tersebut ada tiga masalah yang hendak dijawab dalam penelitian ini, di antaranya: (1) Bagaimanakah efektivitas aspek retorika tulis karangan eksposisi siswa kelas X MIA SMAN 1 Semarapura? (2) Adakah pengaruh brainstorming berbasis copy the master terhadap efektivitas aspek retorika tulis karangan eksposisi siswa kelas X MIA SMAN 1 Semarapura? (3) Bagaimanakah implikasi pembelajaran menulis karangan eksposisi dengan brainstorming berbasis copy the master terhadap pembentukan karakter-bangsa siswa kelas X MIA SMAN 1 Semarapura?

Sejalan dengan masalah tersebut, ada tiga tujuan yang dicapai dalam penelitian ini, yakni mendeskripsikan efektivitas aspek retorika tulis karangan eksposisi siswa kelas X MIA SMAN 1 Semarapura, mendeskripsikan pengaruh brainstorming berbasis copy the master terhadap efektivitas aspek retorika tulis karangan eksposisi siswa kelas X MIA SMAN 1 Semarapura, dan mendeskripsikan implikasi pembelajaran menulis karangan eksposisi dengan brainstorming berbasis copy the master terhadap pembentukan karakter-bangsa siswa kelas X MIA SMAN 1 Semarapura.

\section{Metode}

Penelitian ini menggunakan quasi eksperimen dengan rancangan nonequivalent posttest only control group desaign. Populasi dalam penelitian ini adalah seluruh siswa kelas X MIA SMAN 1 Semarapura yang tersebar dalam tujuh kelas. Dari 7 kelas dipilih 2 kelas sebagai sampel. Penyampelan dilakukan dengan clauster sampling, kemudian dirandom untuk mendapatkan kelompok eksperimen dan kontrol. Dari kegiatan tersebut terpilih kelas X MIA2 sebagai kelompok eksperimen dan kelas X MIA5 sebagai kelompok kontrol. Metode pengumpulan data yang digunakan dalam penelitian ini adalah metode tes dan kuesioner. Metode tes digunakan untuk mengumpulkan data efektivitas aspek retorika tulis karangan eksposisi dengan rubrik penilaian analitik. Metode kuesioner digunakan untuk mengumpulkan data tentang pembentukan karakter bangsa dari kegiatan menulis eksposisi dengan brainstorming berbasis copy the master. Sejalan dengan hal tersebut, penelitian ini menggunakan analisis kuantitatif dan kualitatif. Analisis kuantitatif digunakan untuk menganalisis data efektivitas aspek retorika tulis karangan eksposisi dengan uji-t sampel independen, sedangkan analisis kualitatif digunakan menganalisis data pembentukan karakter bangsa yang diperoleh dari hasil kuesioner. Berdasarkan hal itu, kegiatan analisis data terdiri atas kegiatan pengolahan data dan analisis statistik dengan menggunakan SPSS 17 for Windows. 
IVCEJ, Vol 1 No 2, Tahun 2018

p-ISSN: 2615-4684 e-ISSN: 2615-6938

\section{Hasil dan Pembahasan}

Hasil deskripsi data efektivitas aspek retorika tulis karangan eksposisi dengan metode brainstormning berbasis copy the master dan efektivitas aspek retorika tulis karangan eksposisi dengan metode konvensional disajikan dalam tabel berikut.

Tabel 1. Hasil Perhitungan Skor Efektivitas Aspek Retorika Tulis Karangan Eksposisi

\begin{tabular}{lcc}
\hline & Pembelajaran & A1 \\
Statistik & & A2 \\
\hline Mean & 84.5313 & 72.5000 \\
Std. Error of Mean & 1.07293 & 1.10733 \\
& & \\
Median & 84.0000 & 71.5000 \\
Mode & 84.00 & 67.00 \\
Std. Deviation & 6.06941 & 6.64401 \\
Variance & 36.838 & 44.143 \\
Range & 26.00 & 24.00 \\
Minimum & 70.00 & 62.00 \\
Maximum & 96.00 & 86.00 \\
Sum & 2705.00 & 2610.00 \\
\hline Keterangan
\end{tabular}

Keterangan

A1 : Efektivitas Aspek Retorika Tulis Karangan Eksposisi dengan Brainstorming Berbasis Copy the Master (Kelompok Eksperimen)

A2 : Efektivitas Aspek Retorika Tulis Karangan Eksposisi dengan Metode Konvensional (Kelompok Kontrol)

Hasil deskripsi data dan analisis univariat skor rata-rata efektivitas aspek retorika tulis karangan eksposisi dengan brainstorming berbasis copy the master sebesar 84,5313 dengan simpangan baku simpangan baku (standar deviasi) sebesar 6,06941. Berdasarkan pedoman konvensi rerata efektivitas aspek retorika tulis karangan eksposisi, dapat disimpulkan bahwa rerata efektivitas aspek retorika tulis karangan eksposisi dengan brainstorming berbasis copy the master termasuk dalam kualifikasi sangat tinggi $(84,5313 \geq 75,005)$.

Bila dilihat pada kelompok kontrol, hasil deskripsi data dan analisis univariat rata-rata skor efektivitas aspek retorika tulis karangan eksposisi dengan metode konvensional sebesar 72,5 dengan simpangan baku 6,64401. Berdasarkan pedoman konvensi rerata efektivitas aspek retorika tulis karangan eksposisi, dapat disimpulkan bahwa rerata efektivitas aspek retorika tulis karangan eksposisi dengan metode konvensional termasuk dalam kualifikasi tinggi $(72,5 \geq 58,335 \leq 75,005)$. Ini mengisyarakan bahwa hasil efektivitas aspek retorika tulis karangan eksposisi memiliki hasil yang berbeda antara kelompok eksperimen dan kelompok kontrol.

Berdasarkan analisis uji-t sampel independen tampak bahwa nilai $t_{\text {hit }}=7,761(p=0,000<$ $0,05)$. Ini berarti hipotesis nol $\left(H_{0}\right)$ yang menyatakan bahwa tidak ada pengaruh brainstorming berbasis copy the master terhadap efektivitas aspek retorika tulis siswa SMAN 1 Semarapura ditolak. Jadi, pembelajaran menulis eksposisi dengan brainstorming berbasis copy the master berpengaruh secara signifikan terhadap efektivitas aspek retorika tulis karangan eksposisi. Berdasarkan hal itu, hasil perhitungan univariat menunjukkan bahwa skor rerata efektivitas aspek retorika tulis karangan eksposisi dengan brainstorming berbasis copy the master lebih tinggi daripada skor rata-rata efektivitas aspek retorika tulis karangan eksposisi dengan metode konvensional $(84,5313>72,5)$.

Selain berpengaruh terhadap efektivitas aspek retorika tulis karangan eksposisi, pembelajaran menulis dengan brainstorming berbasis copy the master juga berimplikasi terhadap pembentukan karakter-bangsa siswa SMAN 1 Semarapura. Hal ini terlihat dari hasil analisis univariat data pembentukan karakter-bangsa yang menunjukkan skor rata-rata sebesar 138,1875 dengan simpangan baku 7,02731. Berdasarkan pedoman konvensi rata-rata pembentukan karakter bangsa, rata-rata sebesar tersebut memiliki kualifikasi sangat tinggi. Selain itu, dari pernyataan data angket pembentukan karakter bangsa, sebanyak $60,625 \%$ 
siswa memilih pernyataan sangat sesuai (SS) dengan pembentukan karakter dan sebanyak $39,375 \%$ menyatakan sesuai (S) dengan pembentukan karakter bangsa. Hal itu menandakan bahwa $100 \%$ responden merasakan ada pembentukan karakter bangsa dalam pembelajaran menulis dengan brainstorming berbasis copy the master. Dengan demikian, dalam pembelajaran menulis eksposisi dengan brainstorming berbasis copy the master terdapat implikasi pembentukan karakter bangsa. Jadi, dapat disimpulkan bahwa ada implikasi brainstorming berbasis copy the master dalam pembentukan karakter bangsa siswa SMAN 1 Semarapura.

Keberhasilan penelitian ini menolak hipoteisi nol $\left(\mathrm{H}_{0}\right)$ dan menerima $\left(\mathrm{H}_{\mathrm{a}}\right)$ karena secara teoretis brainstorming berbasis copy the master dapat memberikan kemudahan kepada siswa dalam mengeksporasi ide ke dalam tulisan. Hal ini sejalan dengan pendapat Goshgarian, dkk. (2002:65) yang menyatakan, "Brainstorming can help you get your ideas on paper in an informal and unstructured way. When your brainstorm, you write down as many ideas as you can about your subject, usually in short phrases, question, or single word." (Brainstorming dapat membantu untuk mendapatkan ide-ide dalam kegiatan menulis melalui cara informal dan tidak terstruktur. Ketika melakukan brainstorm, dapat ditulis banyak ide tentang hal pokok atau topik yang biasanya dalam bentuk frasa, pertanyaan atau sebuah kata). Hal itu membuktikan bahwa brainstorming dapat membantu siswa untuk menemukan ide-ide tentang perihal pokok ke dalam tulisan.

Senada dengan pendapat tersebut, Rawlinson (1986:27) menyatakan bahwa braninstorming adalah suatu cara untuk mendapatkan banyak ide dari sekolompok manusia dalam waktu yang sangat singkat. Sayuti (2000:122) berpendapat bahwa brainstorming merupakan langkah eksplorasi dan inventarisasi ide melalui curah pendapat tentang topik tertentu. Senada dengan hal itu, Syafi'le (1988:55) mengungkapkan bahwa brainstorming merupakan cara yang sering digunakan oleh penulis-penulis dalam menemukan perihal pokok yang akan ditulisnya. Karakteristik itulah yang menjadikan brainstorming sebagai metode yang handal dalam pencurahan ide ke dalam sebuah tulisan.

Selain brainstorming, copy the master juga dapat memudahkan siswa dalam menemukan ide yang akan ditulisnya. Mater tulisan yang diberikan kepada siswa memudahkan siswa menggali ide yang akan dicurahkannya. Selain itu, dengan copy the master siswa dimudahkan dalam peniruan model tulisan yang dibuat. Peniruan yang dilakukan bukan berarti sama persis seperti model aslinya, meliankan hanya ditiru konsepnya saja. Sejalan dengan hal itu, Marahimin (2009:21) menyatakan bahwa yang ditiru atau di-copy adalah kerangkanya, idenya, ataupun cara/tekniknya. Oleh karena itu, peniruan dalam hal ini bukan berarti menjiplak tulisannya, melainkan meniru kerangka, ide, atau cara penulisannya untuk mendapatkan tulisan yang baik.

Terkait hal tersebut, copy the master berperan penting dalam keberhasilan penelitian ini. Hal ini sejalan dengan pendapat Rohimat (2012:2), yang menyatakan bahwa teknik copy the master dapat diterapkan pada pembelajaran menulis segingga tujuan pembelajaran dapat tercapai. Menurutnya, teknik tersebut dapat memberikan beberapa hal seperti: (1) pebelajar mendapatkan motivasi positif dalam meningkatkan minat menulis, (2) pebelajar mendapatkan penjelasan mengenai materi karangan, (3) pebelajar mendapatkan model karangan yang dibuat, (4) pebelajar dapat mengembangkan kerangka karangan dari hasil berpikir, dan (5) pebelajar dapat latihan menulis sebagai tes keterampilan menulis. Oleh karena itu, keberhasilan efektivitas aspek retorika tulis karangan eksposisi ini dapat tercapai dengan baik.

Di samping hal teoretis tersebut, keberhasilan brainstorming berbasis copy the master menolak hipoteisi nol $\left(\mathrm{H}_{0}\right)$ dan menerima $\left(\mathrm{H}_{\mathrm{a}}\right)$ disebabkan oleh, secara praktis, pembelajaran menulis dengan brainstorming berbasis copy the master dapat memberikan kesempatan kepada siswa untuk mengeksplorasi ide ke dalam tulisan. Sejak awal pembelajaran, siswa sudah dituntut untuk mengeksporasi ide dari kegiatan brainstrorming dan copy the master. Dari kegiatan inilah siswa dituntut secara aktif mengembangkan ide-ide baru secara berkelompok. Dalam kegiatan tersebut siswa dirangsang untuk menghasilkan kuantitas ide sebanyakbanyaknya. Kesempatan bereksporasi diberikan secara luas sehingga siswa tergugah rasa ingin tahunya dalam mengembangkan suatu ide ke dalam sebuah tulisan. Dengan demikian kegiatan ini dapat merangsang keaktifan siswa dalam berpikir untuk menghasilkan tulisan. Untuk mendapatkan tulisan yang efektif, siswa diberikan kesempatan berpendapat dalam kelompok brainstorming. Dari kegiatan tersebut, ide-ide yang terkumpul dievaluasi dan diramu menjadi tulisan yang efektif. Hal itulah yang menjadikan brainstorming berbasis copy the master mencapai keberhasilan penelitian ini. 
Selain itu, brainstorming berbasis copy the master juga memberikan keberhasilan terhadap pembentukan karakter-bangsa siswa SMAN 1 Semarapura. Hal ini terjadi karena brainstorming berbasis copy the master bersifat inovatif (aktif, efektif, dan menyenangkan). Hal ini sejalan dengan tujuan brainstorming berbasis copy the master yang dapat digunakan untuk (a) mengembangkan pikiran yang kreatif; (b) merangsang partisipasi siswa; (c) mencari kemungkinan pemecahan masalah; (d) mencari metode lainnya; (e) membangkitkan pendapatpendapat baru; dan (f) menciptakan suasana yang menyenangkan dalam kelompok. Sejalan dengan hal itulah brainstorming berimplikasi dalam pembentukan nilai-nilai karakter bangsa, seperti partisipasi (kerja sama), toleransi, pemecahan masalah, dan demokratis, komunikatif, dan bertanggung jawab. Selain itu, dari kegiatan copy the master juga dapat membentuk karakter, seperti jujur, disiplin, mandiri, kreatif, kerja keras, ingin tahu, dan bertanggung jawab. Semua itu, sesuai dengan rumusan Indonesia Heritage Foundation (dalam Zusnani, 2012:119) yang menyatakan bahwa bentuk karakter yang harus ada dalam setiap individu bangsa Indonesia diantarannya: cinta kepada Tuhan dan semesta berserta isinya, tanggung jawab, disiplin dan mandiri, jujur, hormat dan santun, kasih sayang, peduli, kerja sama, percaya diri, kreatif, kerja keras dan pantang menyerah, keadilan dan kepemimpinan, baik dan rendah hati, toleransi, cinta damai dan persatuan. Dengan demikian, brainstorming berbasis copy the master berimplikasi dalam pembentukan karakter bangsa sehingga tercapai seperti hasil dalam penelitian ini.

Selain kontribusi brainstorming berbasis copy the master, keberhasilan pembentukan karakter bangsa juga dikarenakan adanya keterpaduan pembelajaran menulis dengan pendidikan karakter. Dalam kaitannya dengan pendidikan karakter, prosedur pembelajaran menulis merupakan saluran pendidikan karakter. Pada masing-masing tahapan pembelajaran menulis terdapat sejumlah aktivitas yang harus dilakukan siswa. Melalui aktivitas-aktivitas inilah siswa akan secara tidak sadar menujukkan karakter dirinya (Abidin, 2012:197).

Pada tahap pramenulis, siswa dapat melakukan serangkaian aktivitas seperti eksporasi fenomena untuk mendapatkan ide. Pada kegiatan eksplorasi ini siswa sebenarnya membiasakan diri untuk teliti, cermat, peka, antusias, tanggung jawab, kreatif, kritis, inisiatif, dan disiplin. Kebiasaan tersebut sebenarnya adalah sebuah proses pembentukan karakter bangsa pada diri siswa itu sendiri. Pada saat menulis dengan brainstorming berbasis copy the master siswa dibiasakan untuk saling menghargai, kerja sama, tanggung jawab, kreatif, kritis, inisiatif, produktif, ulet, cekatan, suka mengambil risiko, dan berkominmen, serta membentuk nilai karakter bangsa yang lainnya.

Pada tahap penyuntingan, siswa dibiasakan untuk cermat, disiplin, jujur, teliti, analitis, visioner bertanggung jawab, perhatian, sungguh-sungguh, berorientasi pada prestasikomitmen, keterbukaan, kerapian, ketegasan, kehati-hatian, keluwesan, keantusiasan, bekerja keras, dan sejumlah nilai karakter yang lainnya. Pada tahap publikasi (penyampaian di depan kelas) akan terbentuk nilai karakter yang meliputi percaya diri, bangga pada diri sendiri, kreatif, berani, disiplin, sportif, dan amanah. Berdasarkan hal itulah pembelajaran menulis dengan brainstorming berbasis copy the master dapat membentuk pendidikan karakter bangsa, seperti hasil dalam penelitian ini.

Hasil penelitian ini senada dengan penelitian yang dilakukan Pratiwi (2013). Hasil penelitian Pratiwi menunjukkan bahwa teknik brainstorming efektif digunakan dalam pembelajaran menulis puisi berkarakter. Selain sejalan dengan penelitian Pratiwi, penelitian ini juga mendukung penelitian Tina (2013). Hasil penelitiannya menunjukkan bahwa penerapan model pembelajaran partisipatif teknik curah pendapat (brainstorming) dapat meningkatkan proses dan hasil pembelajaran menulis karangan argumentasi siswa kelas X.1 SMA Negeri 2 Tebo. Selain penelitian tersebut, hasil penelitian ini juga sejalan dengan hasil penelitian yang dilakukan oleh Susilowati (2012). Hasil penelitian Susilowati menunjukkan bahwa penerapan metode copy the master mampu meningkatkan minat belajar siswa dan juga mampu meningkatkan kompetensi menulis karya ilmiah siswa. Selanjutnya, hasil penelitian ini juga mendukung hasil penelitian yang pernah dilakukan Hayati (2013). Hasil penelitian Hayati menunjukkan bahwa pengaruh metode copy the master terhadap kemampuan menulis cerpen lebih efektif. Berdasarkan hal tersebut, dapat disimpulkan bahwa penelitian ini sejalan dan dapat melengkapi penelitian yang pernah dilakukan. Hasil penelitian ini pun menunjukkan adanya sumbangan dan kesejalanan dengan penelitian sebelumnya, seperti: (1) metode brainstorming berbasis copy the master mempunyai perbedaan yang signifikan dengan metode konvensional terhadap efektivitas aspek retorika tulis (karangan eksposisi), (2) metode brainstorming berbasis copy the master memiliki keunggulan secara komparatif daripada model pembelajaran konvensional yang diterapkan di kelas kontrol, (3) secara umum metode 
brainstorming berbasis copy the master dapat diterima oleh siswa sebagai suatu kemudahan dalam belajar menulis, (4) metode brainstorming berbasis copy the master dapat meningkatkan keterampilan menulis, (5) metode brainstorming berbasis copy the master berkontribusi dalam membentuk karakter bangsa, (6) metode brainstorming berbasis copy the master memudakkan siswa mengekplorasi ide dan meniru master (kerangka, ide, dan teknik) dalam kegiatan menulis.

\section{Simpulan dan Saran}

Berdasarkan hasil penelitian dan pembahasan di atas dapat disimpulkan bahwa (1) hasil penelitian ini menunjukkan bahwa skor rata-rata efektivitas aspek retorika tulis karangan eksposisi dengan brainstorming berbasis copy the master sebesar 84,5313 dengan kualifikasi sangat tinggi $(84,5313 \geq 75,005)$, sedangkan skor rata-rata efektivitas aspek retorika tulis karangan eksposisi dengan metode konvensional sebesar 72,5 dengan dengan kualifikasi tinggi $(72,5 \geq 58,335 \leq 75,005)$. Ini mengisyarakan bahwa hasil efektivitas aspek retorika tulis karangan eksposisi memiliki hasil yang berbeda antara kelompok eksperimen dan kelompok kontrol, (2) analisis uji-t sampel independen tampak menunjukkan bahwa nilai $t_{\text {hit }}=7,761(\mathrm{p}=$ $0,000<0,05)$. Hal ini menunjukan hipotesis nol $\left(\mathrm{H}_{0}\right)$ yang menyatakan bahwa tidak ada pengaruh brainstorming berbasis copy the master terhadap efektivitas aspek retorika tulis serta implikasinya dalam pembentukan karakter bangsa siswa SMAN 1 Semarapura ditolak. Jadi, pembelajaran menulis eksposisi dengan brainstorming berbasis copy the master berpengaruh secara signifikan terhadap efektivitas aspek retorika tulis. Berdasarkan hal itu, hasil perhitungan univariat menunjukkan bahwa skor rata-rata efektivitas aspek retorika tulis karangan eksposisi dengan brainstorming berbasis copy the master lebih tinggi daripada skor rata-rata efektivitas aspek retorika tulis karangan eksposisi dengan metode konvensional $(84,5313>72,5)$. Hal itu menunjukkan bahwa pembelajaran menulis dengan brainstorming berbasis copy the master lebih efektif daripada metode konvensional dalam membentuk aspek retorika tulis karangan eksposisi, (3) hasil analisis univariat data pembentukan karakter bangsa dalam pembelajaran menulis eksposisi dengan brainstormning berbasis copy the master menunjukkan skor rata-rata pembentukan karakter sebesar 138,1875 dengan simpangan baku 7,02731 . Berdasarkan pedoman konvensi pembentukan karakter bangsa, rata-rata sebesar 138,1875 memiliki kualifikasi sangat tinggi. Selain itu, dari pernyataan data angket pembentukan karakter bangsa, sebanyak 60,625\% siswa memilih pernyataan sangat sesuai (SS) dengan pembentukan karakter dan sebanyak 39,375\% menyatakan sesuai (S) dengan pembentukan karakter bangsa. Hal itu menandakan bahwa 100\% responden merasakan ada pembentukan karakter bangsa dalam pembelajaran menulis dengan brainstorming berbasis copy the master. Dengan demikian, ada implikasi pembentukan karakter bangsa dalam pembelajaran menulis dengan brainstorming berbasis copy the master. Jadi, dapat disimpulkan bahwa ada pengaruh yang signifikan pembelaran menulis eksposisi dengan brainstorming berbasis copy the master terhadap efektivitas aspek retorika tulis karangan ekpsosisi serta implikanya dalam pembentukan karakter bangsa siswa SMAN 1 Semarapura.

Berdasarkan pembahasan dan simpulan di atas, saran yang dapat disampaikan adalah (1) peneliti menyarankan kepada siswa agar menggunakan brainstorming berbasis copy the master dalam belajar menulis, khususnya menulis eksposisi karena dapat mempermudah pencurahan ide dan peniruan teknik tulisan; (2) peneliti menyarankan kepada guru agar pembelajaran dengan brainstorming berbasis copy the master tidak hanya digunakan dalam pembelajaran menulis eksposisi, tetapi juga pada konsep-konsep materi lainnya. Selain itu, guru juga dapat menggunakan brainstorming berbasis copy the master dalam pengembangan karakter bangsa siswa; (3) kepada peneliti lain, penggunaan brainstorming berbasis copy the master dipandang perlu diteliti lebih lanjut dengan pengembangan instrumen yang lebih komprehensif sehingga tidak hanya mengukur tingkat kognitif, tetapi juga pada tingkat analisis sikap maupun keterampilan lainnya; (4) kepada pengambil kebijakan (sekolah dan perguruan tinggi) disarankan agar merekomendasikan hasil penelitian ini untuk meningkatkan keterampilan peserta didik, baik dalam pembelajaran menulis, pembentukan karakter, maupun pembelajaran yang relevan lainnya. 
IVCEJ, Vol 1 No 2, Tahun 2018

p-ISSN: 2615-4684 e-ISSN: 2615-6938

\section{Daftar Pustaka}

Abinin, Yunus. 2012. Pembelajaran Bahasa Berbasis Pendidikan Karakter. Bandung: PT Refika Aditama.

Goshgarian, Gary. 2002. Dialogues An Argument Rhetoric and Reader. New York: United States.

Hayati, Amalia. 2013. "Pengaruh Metode Copy the Master terhadap Kemampuan Menulis Cerita Pendek oleh Siswa Kelas X SMA Nusantara". Artikel (tidak diterbitkan). Jurusan Bahasa dan Sastra Indonesia, Fakultas Bahasa dan Seni Universitas Negeri Medan.

Kartono. 2009. Menulis Tanpa Rasa Takut Membaca Realitas dengan Kritis. Yogyakarta: Kanisius.

Komaidi, Didit. 2011. Panduan Lengkap Menulis Kreatif Teori dan Praktek. Yogyakarta: Sabda Media.

Marahimin, Ismail. 2009. Menulis secara Populer. Jakarta: PT Dunia Pustaka Jaya.

Martha, I Nengah. 2012. Pengantar Retorika. Singaraja: Undiksha.

NS, Sutarno, 2009. Menulis yang Efektif. Jakarta: Sagung Seto.

Pratiwi, Fitria Sari. 2013. "Keefektifan Pembelajaran Menulis Puisi Berkarakter dengan Teknik Brainstorming pada Siswa Kelas VIII SMP Negeri 2 Tegowanu-Grobogan Tahun Ajaran 2012/2013". Skrispi (tidak diterbitkan). Prodi Pendidikan Bahasa dan Sastra Indonesia, FPBS IKIP PGRI Semarang.

Rohimat, Aep. 2013. "Penerapan Teknik Copy The Master dalam Pembelajaran Menulis Karangan Persuasi pada Siswa Kelas X SMA Pasundan 7 Bandung Tahun Ajaran 20122013". Artikel (tidak diterbitkan). Jurusan Pendidikan Bahasa dan Sastra Indonesia FPBS, Universitas Pendidikan Indonesia.

Sayuti, Wahdi, 2000. "Model Pembalajaran Konstrukativisme". Jurnal (tidak diterbitkan). Jurnal Kependidikan, Keislaman dan Kebudayan.

Sudiana, I Nyoman. 2007. Retorika Bertutur Efektif. Sidoarjo: Asri Press.

Susilowati, dkk. 2012. "Peningkatan Kompetensi Menulis Karya IImiah dengan Metode Copy the Master bagi Siswa Kelas XI IPS 1 SMA Negeri 1 Pati”. Jurnal (tidak diterbitkan). Jurnal Penelitian Humaniora, Vol. 12, No. 1, Pebruari 2011 (halaman 51-62).

Syafi'le, Imam. 1988. Retorika Dalam Menulis. Jakarta: Depdikbud Dirjen Dikti P2LPTK.

Tina R.Q., Rangga, dkk. 2013. "Peningkatan Pembelajaran Menulis Argumentasi melalui Model Pembelajaran Brainstorming". Jurnal (tidak diterbitkan). Jurnal Pendidikan Bahasa dan Sastra Indonesia, FBS Universitas Negeri Padang, Vol. 1, No. 2, Maret 2013; Seri A 1-76 (halaman 57-63).

Zusnani, Ida. 2012. Manajemen Pendidikan Berbasis Karakter Bangsa. Yogyakarta: Tugu Publisher. 